\title{
Legislativní regulace sdílené ekonomiky a její odraz \\ ve vnímání občanů České republiky
}

\section{Legislative regulation of the sharing economy and its reflection in the perception of the citizens of the Czech Republic}

\section{Martina Jelínková}

https://doi.org/10.33542/VSS2021-2-01

\begin{abstract}
The article deals with the issue of choosing an appropriate degree of regulation of the sharing economy and its impact on public opinion. Arguments for and against the legislative regulation of sharing are discussed, both in terms of foreign experience and the situation within the Czech Republic in relation to the rules of the European Union. Results of the primary research are presented, the aim of which was to find out how the current state of legal regulation of the sharing economy in the Czech Republic is reflected in the perception of the Czech public. The results of the research clearly show that the public perceives the current legal regulation of the sharing economy as insufficient, which undermines public confidence in it.
\end{abstract}

Keywords: sharing economy, regulation of sharing economy, public opinion, Czech Republic

\section{Úvod}

Ačkoli je sdílená ekonomika již několik let stále na vzestupu, není legislativní rámec regulující její aktivity stále jednoznačně vymezen. To jak v mezinárodním kontextu, tak v rámci České republiky. Objevují se různé pohledy sahající od prosazování tvrdých pravidel až po liberální názory volající po samoregulaci. Zdá se, že optimální bude „zlatá střední cesta“ respektující konkrétní podmínky daného trhu i národních ekonomik. Jisté je, že určitá pravidla jsou potřebná. Pouze tak Ize vytvořit spravedlivé podmínky pro všechny subjekty trhu a zvýšit prestiž a důvěru ve fungování sdílené ekonomiky vočích široké veřejnosti. Současný neradostný stav potvrdil také náš výzkum, jehož výsledky jasně ukazují, že reputace sdílené ekonomiky je vočích české veřejnosti kvůli nedostatečné právní regulaci značně pošramocena. 


\section{Problematika legislativní regulace sdílené ekonomiky}

\subsection{Sdílená ekonomika a její význam}

Pojem „sdílená ekonomika“ se stal nedílnou součástí komunikace laické i odborné veřejnosti. Přesto jeho přesné vymezení není dosud jednoznačné, nebot' zahrnuje celou řadu různých přistupů a forem. Sdílení se totiž může týkat nejrůznějších aktiv (např. předmětů, prostoru, času, peněz, znalostí, informací apod.), může probíhat mezi různými aktéry (např. mezi občany, podniky, státními institucemi atd.) a může být realizováno také různými způsoby (s využitím i bez využití online platforem) (Ertz a kol., 2019). Lze se shodnout na tom, že sdílení umožňuje z podstaty věci přistup k cizím zdrojům. Přes to ale mnozí nesouhlasí se zahrnutím všech aktivit v rámci sdílení pod označení „sdílená ekonomika“. Např. Eckhardt a Bardhi (2015) tvrdí, že termín sdílení by měl být ponechán pouze pro formu sociální směny, která se uskutečňuje mezi známými lidmi, bez záměru realizovat zisk. Dochází-li však ke „sdíleni“ mezi subjekty, kteří se navzájem neznají, nejedná se podle Konupkové (2018) o sdílení, nýbrž o ekonomickou výměnu, kterou Ize označit jako „přístupovou ekonomiku“ (Access Economy). Také zahraniční literatura není v označení různých forem sdílení jednotná a jako synonymum sdílené ekonomiky (Sharing Economy) často používá pojmy Collaborative Economy (např. Vicente, Gil-De-Gómez, 2021) či Platform Economy (Fuster a kol., 2021). V souladu s tím se jeví i pro mnohé české autory jako vhodnější využívání spojení „ekonomika platforem“ (např. Pichrt, 2018; Demová, 2018), kterémužto označení v podstatě odpovídá definice sdílené ekonomiky dle Evropské komise (2016), podle které jde o „obchodní modely, v nichž jsou činnosti usnadňovány platformami pro spolupráci, které vytvářejí otevřený trh pro dočasné využívání zboží nebo služeb často poskytovaných soukromými osobami.“ Vzhledem k tomu, že pro českou veřejnost, která byla předmětem našeho výzkumu, je zřejmě nejznámější označení pro daný fenomén klasické spojení „sdílená ekonomika“ (IPSOS, 2020), je tento pojem $v$ rámci tohoto př́spěvku využíván $v$ této jeho původní podobě.

Hlavním cílem sdílené ekonomiky je využít nevyužívané kapacity (Yu, Shen, 2019). To samozřejmě není nová myšlenka a sdílení v různých formách existovalo ještě před vznikem moderních komunikačních nástrojů a internetu (Pichrt, 2018). Rozsah těchto aktivit byl ale velmi omezen vzhledem $\mathrm{k}$ vysokým transakčním nákladům, které zahrnovaly zejména náklady na vyhledávání a získávání informací. Vznik platforem sdílené ekonomiky tyto transakční náklady výrazně snižil a současně zvýšil velikost trhu a podpořil jeho efektivitu. (Pawlicz, 2019) Současná sdílená ekonomika založená na platformách tedy poskytuje přiležitosti a výhody každému, kdo chce sdílet a konsolidovat své zdroje (Fajar, 2020). Na trh přicházejí nové produkty, nová aktiva i dodavatelé (Dunne, 2018). Prostřednictvím digitálních platforem se „mikropodnikateli“ mohou stát i jednotlivci, kteří pomocí svých nečinných aktiv mohou získat zajímavý př́ijem (Faraj, 2020). Navíc transakční náklady mezi partnery jsou radikálně sníženy, což umožňuje realizovat obchody za ceny mnohem nižší, než jaké nabízejí tradiční 
dodavatelé. Konkurence se tak stává nejen otevřenou, ale i velmi nemilosrdnou. Tito malí a drobní dodavatelé představují hybatele sdílené ekonomiky a jejich sepjetí v rámci platforem tvoří významnou obranu proti silným konkurenčním gigantům (Pichrt, 2018). Sdílená ekonomika je tedy dynamickým a efektivním příkladem konkurence, která brání vzniku monopolu (Dunne, 2018).

\subsection{Právní nejednoznačnost z hlediska účastníků sdílení}

Jak je z dat patrné (např. IPSOS, 2020), obchodní model sdílení se rozrůstá a začíná posouvat tradiční obchodní model (Pawlicz, 2019). Oproti klasickým obchodním systémům nepředstavuje sdílená ekonomika v zásadě žádný významný rozdíl. Každá strana může volně vstoupit na trh formou spolupráce a sdílení zdrojů s ostatními (Lee,Tan, 2019), (Jones, 2014). Nicméně paradigma trhu se změnilo poměrně radikálně. Na trhu se objevují noví hráči, u kterých je obtižné přesně určit jejích osobní statut i vzájemný vztah v rámci platného právního systému, tak že se stávající předpisy jeví jako zastaralé (Pawlicz, 2019). Otázku problematičnosti správné legislativní interpretace můžeme vysledovat u všech účastníků trhu sdílené ekonomiky, kterými jsou (Elischer, Mocek, 2018):

- Uživatelé (fyzické či právnické osoby, která nedisponují potřebnými aktivy, zdroji či dovednostmi, a využívají tak nabízených služeb poskytovatele) - uživatele můžeme chápat jako určité „kvazispotřebitele“, kteří by měli být chráněni právem. Nicméně pokud partnerem uživatele v obchodním vztahu není podnikatel (což mnohdy v rámci sdílené ekonomiky není), nelze právo na ochranu spotřebitele v současné podobě aplikovat. Podle Elischera a Mocka (2018) je třeba spíše uvažovat o určité ochraně obou smluvních stran motivované absencí informační transparentnosti na obou stranách: smluvní strany se navzájem neznají a v některých případech se ani osobně poznat nemohou.

- Poskytovatelé (fyzické či právnické osoby, která disponuji aktivy, zdroji či dovednostmi a za účelem přivýdělku či snižení svých nákladů v době, kdy dané statky nevyužívají, je pronajímá či jinak sdílí). Zde je klíčové určit, zda daná osoba má statut podnikatele či nikoli. Stávající právní úprava zatím nezohledňuje odlišnosti a parametry sdílené ekonomiky. Pro určení toho, zda jde o podnikatele či soukromou osobu Ize využít pouze určitá vodítka, jako je (Elischer, Mocek, 2018): četnost poskytování služeb; motiv usilování o zisk; výše obratu. Obdobně Staša (2018) tvrdí, že sdílení nemusí být podnikáním, pokud jde o neprofesionální, nevýdělečné a nesoustavné sdílení. Dle statutu podnikatele či nepodnikatele poskytovatele mohou být odvozeny prípadné odpovědnostní důsledky. Tento problém byl hojně diskutován zejména $v$ souvislosti s platformou Airbnb zprostředkující krátkodobé ubytování. Pokud ubytovací činnost ubytovatelů naplňuje znaky podnikání (tzn., že je provozováno soustavně a evidentně za účelem zisku), pak podléhá živnostenskému zákonu (Balounová, Jílková, 2018) a ubytovatel je povinen platit daň 
z príjmů, daň z přidané hodnoty, ubytovací poplatky a vést evidenční knihu ubytovaných. Dle Vládní analýzy k tématu sdílené ekonomiky z června 2017 znak soustavnosti splňuje cca $80 \%$ ubytovatelů Airbnb. (Tkadlec, 2018) Přes to je kontrola ubytovatelů v rámci sdílené ekonomiky pro veřejnou právu značně obtižná a mnoho „podnikatelư“ zatím zákonu uniká. Druhým problémem z hlediska poskytovatelů služeb je jejich postavení vůči digitální platformě, jejímž prostřednictvím své služby nabízejí. Při analyzování vztahů v rámci platforem práce došlo již mnoho autorů k závěru, že vztah platforem a poskytovatelů (pracovníků) nenaplňuje všechny definiční znaky závislé práce, nýbrž se svou podstatou dají zařadit na půli cesty mezi klasické zaměstnance a osoby samostatně výdělečně činné. Na úrovni světové oborné veřejnosti se tak již delší dobu diskutuje o vytvoření tzv. „mezikategorie“ nebo „třetí kategorie“ pracovníků, která již funguje v právním systému např. v Británii či v Německu. (Demová, 2018; Kubešová, 2019)

- Digitální platforma - jde v podstatě o technického prostředníka (zprostředkovatele), který propojuje uživatele a poskytovatele konkrétních služeb na online bázi (Elisher, Mocek, 2018). Postavení platforem je zřejmě nejvíce právně nejasné, protože je problém určit, zda platforma vystupuje jako profesionál či nikoli. Ačkoli digitální platformy hrají ústřední roli ve sdílené ekonomice, bohužel většina $z$ nich působí $v$ šedé regulační zóně nebo v právním vakuu (Whelan, 2017), kde to, co je legální nebo nezákonné, zůstává nejasné, a kde stávající legislativa není vhodná k tomu, aby dohližela na jejich nově vznikající postupy a technologický vývoj (Berkowitz, Souchaud, 2019). Určení postavení platformy ve vztahu k poskytovatelům aktiv, je pak rozhodující k posouzení jejich vzájemného vztahu, tedy zda jde o vztah zaměstnanec - zaměstnavatel či je poskytovatel v roli podnikatele, který nese veškerou odpovědnost. Problematické je pak zajištění alespoň minimálních práv pracovníků a tedy i možnost horších pracovních podmínek co se týká pracovní doby, doby odpočinku, bezpečnosti a ochrany zdraví při práci či výše odměny, která často nedosahuje výše minimální mzdy nebo jejího ekvivalentu (Kubešová, 2019). Nejasná je také problematika odpovědnosti pracovníků postih př́padných deliktů (např. vymáhání pokut). Netransparentnost fungování platforem může navíc zakrývat diskriminaci a nerovné zacházení i možnost nelegálního zaměstnávání (Demová, 2018). Nedostatek jasných pravidel pak samozřejmě vede platformy k tomu, že si automaticky vybírají príznivější předpisy (Pawlicz, 2019) a snaží se vyhnout vlastní odpovědnosti i např. daňovým povinnostem (Hájek, 2019). V této souvislosti jsou veřejně asi nejznámější spory provozovatelů taxislužeb splatformami Uber, které se snažily tvárit jako pouzí zprostředkovatelé spolujízdy a obcházely obecně platná pravidla pro provozování přepravních služeb. $V$ současnosti Ize $z$ různých rozsudků v rámci Evropské unie dovozovat, že zprostředkovatelskou službu typu Uber a Taxify nelze považovat za „službu informační společnosti“, nýbrž splňuje kvalifikaci „služba v oblasti dopravy“, na kterou se 
vztahují zvláštní pravidla volného pohybu služeb ve smyslu společné dopravní politiky. Je tedy věcí členských států Evopské unie, jakým způsobem budou zprostředkovatelskou službu tohoto typu regulovat. (Klíma, 2019)

Z výše uvedených základních problematických oblastí u všech účastníků sdílené ekonomiky jasně vyplývá, že vymezení určitých pravidel pro sdílenou ekonomiku je aktuální problém.

\subsection{Argumenty pro i proti různým způsobům regulace sdílené ekonomiky}

Je zřejmé, že regulace sdílené ekonomiky jako obvykle pokulhává za technologickými inovacemi. To platí nejen v České republice, ale celosvětově. Vlády v různých zemích reagují pomalu a vytvářejí předpisy, které se tomuto novému obchodnímu modelu snaží príizpưsobit. (Faraj, 2020) Zdá se, že samotní účastníci trhu sdílené ekonomiky se spíše než aby toužili po regulaci, zajímají o to, jak vyhovět současným podmínkám. Ani odborníci se zatím neshodli, zda problémy $v$ oblasti regulace sdílené ekonomiky je třeba řešit přísnými pravidly či postačí mírná regulace (Berkovitz, Souchaud, 2019). Pawlicz (2019) uvádí, že regulace může ochromit pobídky pro inovace zvýšením nákladů a snížením potenciální návratnosti, a tím znemožnit nebo zabránit novému vstupu a zbavit spotřebitele výhod nových nabídek produktů a služeb. Zavádění nových předpisů, které by zakázaly nebo výrazně omezily oblast sdílené ekonomiky, by tedy podle těchto autorů mohlo vést $\mathrm{k}$ menším pobídkám pro budoucí inovátory a v důsledku toho ke snižení ekonomické efektivity. Někteří diskutující naopak tvrdí, že je zapotřebí silný regulační rámec, protože platformy zatím nejsou natolik konsolidované, aby dosáhly na seberegulaci (Chaffee, Rapp 2012). Cohen a Sundararajan (2015) však v samoregulaci ze strany ekonomických hráčů vidí východisko $v$ dané situaci, které by přispělo $k$ inovacím a rozvoji sdílené ekonomiky. $\mathrm{K}$ tomuto názoru se částečně přiklání i Berkovitz a Souchaud (2019), kteři doporučují hybridní přístup regulace a společné samoregulace. Ten by, podle jejich názoru, měl kombinovat měkkou vládní regulaci a samoregulaci prostřednictvím částečné meta-organizace sdružující zúčastněné subjekty trhu. Autoři vycházejí z toho, že právo mohou regulovat sami účastníci trhu (samoregulace) prostřednictvím sociální smlouvy zúčastněných stran. Tato sociální dohoda je základem pro vytváření asociací, které mohou regulovat a bránit své zájmy a které jejich členové respektují, protože svoboda je zásadní pro posun komunity k zamýšlenému cíli. Jednoznačně se k míre vládní regulace nestaví ani čeští odborníci. Například Pichrt (2019) uvádí:“ Bylo by vhodné provést hloubkovou analýzu toho, nakolik je potřebné respektive nezbytné $v$ reakci na mnohé praktické projevy „ekonomiky sdílení" upravit náš právní rád tak, aby nebyl v této oblasti brzdou společensko-ekonomického vývoje, a také identifikovat oblasti, kde takové změny právního systému nejsou potřebné a kde by mohly být projevem snah některých podnikatelských skupin opatřit si na trhu „do práva vepsanou“ výhodu proti svým konkurentům." 
Další otázkou je, na jaké úrovni by regulace sdílené ekonomiky měla probíhat. Většina odborníků tvrdí, že nejefektivnější úrovní je úroveň měst a obcí (Wegmann, Jiao, 2017; Park, 2020). Přesto se mnozí odkazují na americký právní systém (např. Hong, Lee, 2018). Evropští vědci použivají centralističtější přístup a někdy dokonce shledávají regulaci EU jako nejefektivnější, protože činí lobbistické činnosti obtižnými a nákladnými (Pawlicz, 2019). To si myslí i Elichetr a Mocek (2018), kteři poznamenávají, že legislativní impuls (alespoň ten primární) regulace sdílené ekonomiky by měl vzejít z pera evropského zákonodárce, nebot' tato sféra tvoři jednu z hlavních zájmových regulatorních oblastí Evropské unie. Také Greguš a Adamička (2019) se domnívají, že by legislativní změna v oblasti sdílené ekonomiky měla, vzniknou zejména $v$ rámci mezinárodního a evropského práva a následně za pomoci implementačních a harmonizačních sekundárních pramenů evropského práva by měly členské státy EU uvedené legislativní změny včlenit do svých vnitrostátních právních systémů.

\subsection{Současné trendy řešení regulace sdílené ekonomiky v České republice}

$Z$ hlediska nastolení efektivní regulace sdílené ekonomiky je v České republice, ale i celosvětově, hlavním úskalím nedostatek informací, s nimiž státní správa disponuje. Data získaná z platforem jsou často jediným způsobem, jak potřebné informace shromáždit, přičemž většina platforem není př́liš ochotna spolupracovat (Frenken, Schor, 2017). Také podle Ministerstva financí ČR je „zásadním problémem informační deficita ve vztahu k jednotlivým transakcím přes př́slušné internetové platformy“. (Vybíral, 2018) Přestože na unijní i vnitrostátní úrovni ČR existují normy upravující problematiku výměny informací např. podle zákona o mezinárodní spolupráci při správě daní nebo mezinárodních smluv o zamezení dvojího zdanění, může být využití těchto nástrojů zdlouhavé a neefektivní. Proto správce daně, resp. stát hledá i další nástroje, jako různé dohody a memoranda mezi zúčastněnými stranami (např. dohoda mezi vládou ČR a společností Uber z oku 2018 o předávání informací). (Boháč, 2019) Jejich efektivita je ale diskutabilní (Pichrt, 2018). Dále je pak zásadní dle Boháče (2019) z hlediska dodržování nastolených pravidel regulujících sdílenou ekonomiku provádět osvětu a kontroly. $V$ této oblasti se $v$ České republice začalo blýskat na lepší časy. Například $v$ říjnu 2017 zveřejnila Finanční správa ČR dokument označený „Informace k daňovému posouzení povinností poskytovatelů ubytovacích služeb (Airbnb a další)“ (Finanční správa, 2017), představující velmi rozsáhlou metodickou pomůcku týkající se oblasti daně z přidané hodnoty, daní z př́jmů a elektronické evidence tržeb. V srpnu 2018 pak Finanční správa ČR provedla „velký zátah proti řidičům Uberu a pronajímatelů Airbnb bytů, které začala hromadně obesílat s výzvami k doplacení daní." (Finanční správa, 2018) Také v oblasti právní regulace na poli sdílené ekonomiky dochází v posledních letech sice $\mathrm{k}$ pomalému, ale znatelnému posunu. Napřiklad Evropský parlament, přijal v r. 2019 návrh Směrnice o transparentních a předvídatelných pracovních podmínkách v EU (Evropský parlament, 2019), kterou navrhl a 
schválil soubor minimálních práv ke zvýšení minimální ochrany pracovníků. Cílem směrnice je zvýšit předvídatelnost pracovních podmínek a transparentnost práce $v$ jejich nových formách, jakou je i práce pro digitální platformy a snízit tak možnost zneužívání flexibility pracovníků. Konečný text směrnice schválila Rada EU a následně mají členské státy tři roky na její transpozici. Určitý impuls pro regulaci sdílené ekonomiky voblasti ubytovacích služeb znamenala v rámci České legislativy novela zákona o místních podpatcích (Ministerstvo financí České republiky, 2021) Podle této novely se místo dřívějších místních poplatků za lázeňský/rekreační pobyt a z ubytovací kapacity nově zřizuje jen poplatek z pobytu. Zavést ho může jakákoliv obec a týká se pobytu na libovolném místě v obci bez ohledu na to, zda je ono místo k pobytu kolaudováno či ne. To zrovnoprávnilo podmínky pro klasické i alternativní ubytovací služby. Vzhledem k pandemii Covid-19, která způsobila dramatický pokles cestovního ruchu, ale $\mathrm{k}$ využití kompenzačního potenciálu těchto poplatků většina českých měst $v$ roce 2021 nepřistoupila.

Je zřejmé, že mnohé další kroky a přijímání regulačních opatření byly zbrzděny právě pandemií Covid-19. To je pochopitelné, nicméně doufejme, že se situace brzy dostane do normálu. Čím déle totiž existuje stav „dvojího trhu“ (kdy jeden je přísně regulovaný a druhý téměř nekontrolovaný), tím lépe pro ty, kteří z tohoto stavu získávají neoprávněné výhody a s nesrovnatelně nižšími náklady získávají větší podíl na trhu. (Pichrt, 2019) Zdá se, že mnohdy i česká veřejnost získala dojem, že se mnohé podnikání v rámci sdílené ekonomiky (at' již $v$ podobě kvazihotelů, př́padně kvazitaxislužeb) nějak (neznámo jak) vymyká z běžného podnikání. Tuto názorovou pomýlenost se teprve v posledních letech snaží vyvracet svými zásahy především odborná veřejnost a finanční správa (Vybíral, 2018). To zda a jak se různé způsoby regulace, či spiše neregulace, sdílené ekonomiky odrážejí ve vnímání široké veřejnosti, zatím nebylo předmětem vědeckého zájmu (Connoly, 2021). K odstranění tohoto nedostatku v rámci České republiky jsme se pokusili přispět naším výzkumem, jehož cílem bylo $v$ obecné rovině zjistit, zda cítí česká veřejnost nejistotu, riziko a nedostatek regulace ohledně fungování sdílené ekonomiky v naší vlasti. Výsledky našeho výzkumu jsou prezentovány dále.

\section{Výzkum postojů české veřejnosti vůči rizikům vyplývajícím z nedostatečné legislativní regulace sdílené ekonomiky}

\subsection{Výzkumné hypotézy a metodologie výzkumu}

Jak bylo naznačeno v předchozích kapitolách, stanovení přiměřené míry legislativní regulace sdílené ekonomiky je zatím celosvětovým problémem. Je přirozené, že tuto nejistou situaci pak mají tendenci využívat podvodníci a filutové, kteří se snaží díry v zákoně využít ve svůj prospěch. To je samozřejmě neetické a společensky nepřípustné. Zdá se, že zejména 
medializace problémů, především různé kauzy se společnostmi Uber a Airbnb, mohly u světové, ale i u české veřejnosti narušit dobré jméno sdílené ekonomiky jako celku. Daný předpoklad potvrzuje i Soběhart (2018), který tvrdí, že důvodem kontraverzního vnímání sdílené ekonomiky z pohledu občanů České republiky (dále ČR), je její nedostatečné regulace. To pak může být problémem pro další rozvoj tohoto moderního fenoménu, nebot' zapojit se do sdílení, které, jak mnozí potvrzují, je pozitivním trendem podporující udržitelnost (např. Heinrichs, 2013), může být spojeno s pocity rizika, nejistoty a podpory něčeho nekalého. $\mathrm{Na}$ základě těchto předpokladů byly stanoveny následující výzkumné hypotézy:

H1: Hlavním důvodem nezapojení se českých občanů do sdílené ekonomiky je nejistota pramenící z nedostatečné či nejasné právní úpravy.

H2: Občané ČR vnímají sdílenou ekonomiku jako rizikovou, nebezpečnou a nedostatečně legislativně regulovanou.

Zajímavým aspektem zjištěným při výzkumech názorů veřejnosti na sdílenou ekonomiku je skutečnost, že se názory občanů často liší podle pohlaví, věku a vzdělání. Obvykle pozitivněji na sdílenou ekonomiky nahližejí muži než ženy, lépe ji prijímá mladší generace a lidé s vyšším vzděláním (Andreotti a kol., 2017). V našich předchozích výzkumech týkajících se prínosů sdílené ekonomiky, se ale naše předpoklady o rozdílnosti názorů respondentů z řad české veřejnosti dle pohlaví, věku a vzdělání nepotvrdily (Jelínková a kol, 2021). Je tedy zajímavé zjistit, zda toto platí i v prípadě názorů české veřejnosti na rizikovost, bezpečnost a dostatečnost legislativní regulace sdílené ekonomiky $v$ ČR. Na základě našich předchozích výzkumů Ize stanovit následující hypotézu:

H3: Názory na rizikovost, bezpečnost a míru legislativní regulace sdílené ekonomiky $v$ ČR se dle pohlaví, věku a vzdělání respondentů neliší.

Výzkum zjišt'ující postoje české veřejnosti vůči různým aspektům sdílené ekonomiky byl proveden v letech 2020/2021 ve spolupráci se studenty Fakulty chemicko - technologické Univerzity Pardubice. Vzhledem k problematické epidemiologické situaci související s pandemií Covid-19 byla zvolena forma elektronického (on-line) dotazování prostřednictvím dotazníků poskytovaných přes Internet. Tato metoda byla vybrána zároveň i proto, že jde o relativně levnou, rychlou a spolehlivou metodu, umožňující zasáhnout velkou a rozptýlenou skupinu respondentů (Tomaselli, 2021). Elektronický dotazník byl na základě předchozí osobní domluvy tazatelů $z$ řas studentů Univerzity Pardubice respondentům zpř́stupněn prostřednictvím aplikace LimeSurvey. Osloveni byly zástupci české veřejnosti starší 18 let na základě kvótního výběru, kdy za kvótní znaky byly zvoleny věk a pohlaví. Data se podařilo získat celkem od 614 respondentů. Struktura respondentů odpovídá struktuře české veřejnosti dle daných kvótních znaků zjištěné na webových stránkách Českého statistického úřadu (data k 31. 12. 2019). Podrobně o struktuře respondentů informuje tabulka č. 1. 
Tabulka 1: Struktura respondentů výzkumu

\begin{tabular}{|c|c|c|}
\hline & Absolutní četnost & Relativní četnost (\%) \\
\hline \multicolumn{3}{|l|}{ Vĕk } \\
\hline 18-29 let & 224 & 36 \\
\hline 30 a více let & 390 & 64 \\
\hline \multicolumn{3}{|l|}{ Pohlaví } \\
\hline Muž & 277 & 45 \\
\hline Žena & 337 & 55 \\
\hline \multicolumn{3}{|l|}{ Vzdělání } \\
\hline Základní a středoškolské & 455 & 74 \\
\hline Vysokoškolské & 159 & 26 \\
\hline
\end{tabular}

Zdroj: Vlastní zpracování

V rámci primárního výzkumu byly nejprve zjištovány důvody, proč respondenti nejsou zapojeni do sdílené ekonomiky jako uživatel či jako poskytovatel nevyužívaných aktiv. Byla využita bipolární škála (ano/ne), kdy se respondenti vyjadřovali ke každému z uvedených důvodů jednotlivě. $V$ rámci dotazníku mohli také respondenti volně připsat individuálně pocit’ovaný důvod své neangažovanosti, který nebyl $v$ dotazníku specifikovaný. $V$ druhé části výzkumu byly na čtyřstupňové Likertově škále, kde 1 = rozhodně nesouhlasím, 2 = spíše nesouhlasím, 3 = spíše souhlasím, 4 = rozhodně souhlasím, zjištovány postoje respondentů jako míra souhlasu či nesouhlasu s devíti výroky vyjadřujícími různý pohled na bezpečnost, rizikovost, důvěryhodnost a míru regulace sdílené ekonomiky v ČR. Data byla statisticky zpracována s využitím statistického softwaru IBM SPSS Statistics, verze 24 . Ve všech prípadech byly odpovědi respondentů popsány prostřednictvím absolutních a relativních četností odpovědí u jednotlivých stupňů využitých škál. Zjištěné postoje respondentů $\mathrm{k}$ bezpečnosti, rizikovosti, důvěryhodnosti a míře regulace sdílené ekonomiky byly charakterizovány též prostřednictvím průměru a mediánu úrovně hodnocení respondentů. Statistické rozdily mezi názory respondentů podle pohlaví, věku a vzdělání byly hodnoceny s využitím Pearsonova chí-kvadrát testu na hladině významnost i 0,05 (tzn. sig. < 0,05). Identifikované statistické rozdíly jsou v tabulce označeny tučně.

\subsection{Výsledky výzkumu}

Úvodní snahou našeho výzkumu bylo zjistit, jaké jsou důvody respondentů pro jejich zapojení či nezapojení do sdílené ekonomiky, a to byt' jako uživatel či jako poskytovatel sdílených statků. Zajímalo nás, zda neaktivita respondentů ve sdílené ekonomice nesouvisí 
s nedostatečným právním zázemím či nepřiměřenými legislativními zásahy $v$ dané oblasti. Výsledky prezentují následující tabulky číslo 2 a číslo 3.

Do sdílené ekonomiky jako její uživatel (spotřebitel, klient) není zapojeno 403, tj. $66 \%$ respondentů. Důvody, proč respondenti nejsou zapojeni jako uživatelé do sdílené ekonomiky, uvádí následující tabulka č. 2. Tabulka znázorňuje absolutní četnosti respondentů, kteří vždy souhlasí s daným důvodem a následně relativní četnosti respondentů vypočítané jako poměr z celkového počtu těch, kteři do sdílené ekonomiky jako uživatelé zapojeni nejsou.

Tabulka 2: Důvody nezapojení se respondentů do sdílené ekonomiky jako uživatel

\begin{tabular}{|l|c|c|}
\hline Důvod nezapojení jako uživatel & Absolutní četnost & Relativní četnost (\%) \\
\hline Nedostatek informací & 189 & 37 \\
\hline Nedůvěra & 152 & 37 \\
\hline Vyhovuje mi, co je běžné & 149 & 35 \\
\hline Takové služby nepotřebuji & 143 & 18 \\
\hline Nebezpečnost & 72 & 12 \\
\hline Nedostupnost & 49 & 10 \\
\hline Nedostatečná právní ochrana & 47 & 3 \\
\hline Př́lišná modernost & 41 & 12 \\
\hline Negativní zkušenost & 12 & \\
\hline
\end{tabular}

Zdroj: Vlastní zpracování

Jak vyplývá z tabulky č. 2 „nedostatečnou právní ochranu“ jako důvod svého nezapojení se jako uživatel do sdílené ekonomiky uvedlo pouze 12\% nezapojených respondentů. Nicméně poměrně značné procento respondentů uvedlo jako důvod „nedůvěru“ (38\%) a nezanedbatelné procento také „nebezpečnost“ (18\%), kteréžto aspekty s mírou právní ochrany spotřebitele mnohdy úzce souvisejí. Téměř polovina respondentů vidí jako důvod své uživatelské neangažovanosti v rámci sdílené ekonomiky „nedostatek informaci“. To Ize tedy chápat jako zásadní problém limitující chut’ občanů zapojit se do sdílené ekonomiky jako uživatel, a tedy jako hlavní faktor omezující její efektivní fungování. $\vee$ této oblasti tedy spočívá hlavní úkol pro př́slušné orgány, tedy „zvýšit informovanost české veřejnosti“. 
Další výzkumnou otázkou bylo zjistit, z jakých důvodů nejsou respondenti zapojeni do sdílené ekonomiky jako poskytovatelé. Poskytovatelem výrobků či služeb ve sdílené ekonomice není 573, tj. 93\% respondentů, jejichž důvody neangažovanosti v rámci sdílené ekonomiky shrnuje následující tabulka č. 3 . $\vee$ tabulce jsou opět vyjádřeny nejprve absolutní četnosti souhlasných odpovědí respondentů, které jsou následně přepočíány jako procentuální podíl z těch, kteří jako poskytovatelé do sdílené ekonomiky zapojeni nejsou.

Tabulka 3: Důvody nezapojení se respondentů do sdílené ekonomiky jako poskytovatel

\begin{tabular}{|l|c|c|}
\hline Důvod nezapojení jako poskytovatel & Absolutní četnost & Relat. četnost (\%) \\
\hline Nechci nic sdílet & 300 & 52 \\
\hline Nemám nic, co Ize sdílet & 252 & 44 \\
\hline Nedostatek času & 180 & 31 \\
\hline Obavy o majetek (o sebe) & 157 & 27 \\
\hline Nedostatek informací & 129 & 23 \\
\hline Nejasná právní úprava & 64 & 11 \\
\hline Náročnost naplnění legislativních požadavků & 44 & 8 \\
\hline Nevyplatí se to & 41 & 7 \\
\hline Negativní zkušenost & 10 & 2 \\
\hline Negativní vliv na okolí & 10 & 2 \\
\hline
\end{tabular}

Zdroj: Vlastní zpracování

Přestože legislativní problémy nepatří k nejčastějším důvodům pro to, že respondenti nejsou zapojeni do sdílené ekonomiky jako poskytovatelé, je nutné je brát zajisté také v potaz. Tím spiše, že někteři respondenti jako další individuálně sdělené důvody své neúčasti na sdílení v roli poskytovatele uváděli svůj nepřijemný pocit s narušení konkurenční soutěže, pocitované nerovné podmínky a obavu ze státní represe.

Hlavním záměrem našeho výzkumu bylo zjistit názory české veřejnosti na bezpečnost, rizikovost a důvěryhodnost využivání služeb sdílené ekonomiky a také na úroveň její právní regulace. Postoj respondentů vůči různým výrokům charakterizující specifické pohledy na danou problematiku spojenou s fungováním sdílené ekonomiky uvádí následující tabulka č. 4. Výroky jsou seřazeny sestupně dle klesající míry souhlasu respondentů s nimi. 
Tabulka 4: Postoje respondentů k bezpečnosti, rizikovosti, důvěryhodnosti a regulaci sdílené ekonomiky

\begin{tabular}{|c|c|c|c|c|c|c|c|}
\hline \multirow{2}{*}{ Výrok } & \multicolumn{4}{|c|}{ Absolutní četnost $^{*}$} & \multirow{2}{*}{$\begin{array}{c}3 \& 4 \\
(\%)\end{array}$} & \multirow{2}{*}{ Medián } & \multirow{2}{*}{ Průmě } \\
\hline & 1 & 2 & 3 & 4 & & & \\
\hline $\begin{array}{l}\text { Poskytování služeb (produktů) v rámci } \\
\text { sdílené ekonomiky je spojené s vyšším } \\
\text { rizikem nedodržení dohodnutých } \\
\text { podmínek, než klasický model podnik- } \\
\text { zaměstnanec-zákazník }\end{array}$ & 12 & 126 & 318 & 158 & 78 & 3 & 3,01 \\
\hline $\begin{array}{l}\text { Sdílená ekonomika by v České } \\
\text { republice měla být více regulována }\end{array}$ & 36 & 145 & 329 & 104 & 71 & 3 & 2,82 \\
\hline $\begin{array}{l}\text { Využívání služeb sdílené ekonomiky je } \\
\text { spojené s vyšším rizikem nekvality } \\
\text { služeb (produktů), než klasický model } \\
\text { podnik-zákazník }\end{array}$ & 27 & 182 & 302 & 103 & 66 & 3 & 2,78 \\
\hline $\begin{array}{l}\text { Poskytovatelé platforem se snaží zůstat } \\
\text { anonymní, což je nedůvěryhodné }\end{array}$ & 33 & 212 & 237 & 132 & 60 & 3 & 2,76 \\
\hline $\begin{array}{l}\text { Častým motivem pro zapojení subjektů } \\
\text { do sdílené ekonomiky v České } \\
\text { republice je možnost beztrestně } \\
\text { porušovat platnou legislativu }\end{array}$ & 53 & 269 & 230 & 62 & 48 & 2 & 2,49 \\
\hline $\begin{array}{l}\text { Využívání služeb sdílené ekonomiky je } \\
\text { bezpečné }\end{array}$ & 74 & 292 & 220 & 28 & 40 & 2 & 2,33 \\
\hline $\begin{array}{l}\text { Poskytování služeb (produktů) v rámci } \\
\text { sdílené ekonomiky je bezpečné }\end{array}$ & 69 & 302 & 220 & 23 & 40 & 2 & 2,32 \\
\hline $\begin{array}{l}\text { Sdílená ekonomika je v České } \\
\text { republice dostatečně regulována } \\
\text { současnými zákony }\end{array}$ & 80 & 344 & 170 & 20 & 31 & 2 & 2,21 \\
\hline $\begin{array}{l}\text { Sdílená ekonomika je v České } \\
\text { republice regulována a kontrolována } \\
\text { výrazně lépe než v zahraničí }\end{array}$ & 93 & 393 & 110 & 18 & 21 & 2 & 2,09 \\
\hline
\end{tabular}

*Použitá škála: 1 = rozhodně nesouhlasím; 2 = spíše nesouhlasím; 3 = spíše souhlasím; 4 = rozhodně souhlasím

Zdroj: Vlastní zpracování 
Tabulka č. 4 jasně ukazuje, že většina respondentů vnímá vyšší rizikovost využívání služeb sdílené ekonomiky než v tradičních ekonomických modelech, a to jak z pohledu uživatelů, tak poskytovatelů a také jejich nižší vnímanou bezpečnost. Ačkoli většina respondentů $(60 \%)$ souhlasí s určitou neprůhledností a netransparentností ve vlastnických strukturách digitálních platforem, více jak polovina oslovených (52\%) se nedomnívá, že by častým motivem pro zapojení se do sdílené ekonomiky byla možnost beztrestně porušovat platnou legislativu. Jednoznačně z výzkumu vyplývá pocit nedostatečné právní regulace $v$ této oblasti, nebot' $71 \%$ respondentů se domnívá, že sdílená ekonomika by měla být v České republice více regulována, nebot' zatím dostatečně regulována není (souhlasí 69\% respondentů) a rozhodně není lépe regulována než v zahraničí (souhlasí $79 \%$ respondentů).

Dalším naším záměrem v rámci analýzy dat získaných výzkumem bylo zjistit, zda se liší názory respondentů na různé aspekty bezpečnosti, rizikovosti, transparentnosti a regulace sdílení podle různých charakteristik respondentů. Co se týká rozdílnosti názorů respondentů podle pohlaví, statisticky významný rozdíl byl Pearsonovým chí-kvadrát testem prokázán pouze u výroku „častým motivem pro zapojení subjektů do sdílené ekonomiky v České republice je možnost beztrestně porušovat platnou legislativu“ $\left(x^{2}=8,800\right.$; sig. $\left.=0,003\right)$, kdy muži s tímto tvrzením souhlasí statisticky významně více než ženy. $U$ ostatních osmi výroků statisticky významný rozdíl na základě pohlaví nalezen nebyl. Obdobně malá rozdílnost $v$ názorech respondentů na danou problematiku byla zjištěna u analýzy rozdílů podle vzdělání. Zde se názory respondentů statisticky významně liši pouze ve dvou prípadech, a to u výroku „poskytovatelé platforem se snaží zůstat anonymní, což je nedůvěryhodné“ ( $x^{2}=5,579$; sig. = 0,018)a u tvrzení „sdílená ekonomika je v České republice regulována a kontrolována výrazně lépe než v zahraniči“ $\left(X^{2}=4,303\right.$; sig. $\left.=0,038\right)$, kdy v obou případech s danými tvrzeními souhlasí statisticky významně více lidí $s$ nižším vzděláním než vysokoškolákủ. $U$ zbylých sedmi zkoumaných výroků statisticky významné rozdily v názorech respondentů podle vzdělání zjištěny nebyly. Nejvýrazněji se rozdíly v názorech respondentů u zkoumaných výroků projevily při zjišt’ování statistických rozdílů podle věku respondentů. Výsledky statistického zpracování znázorňuje tabulka číslo 5. 


\begin{tabular}{|c|c|c|c|c|}
\hline \multirow[b]{2}{*}{ Výrok } & \multicolumn{2}{|c|}{ Relativní četnosti } & \multicolumn{2}{|c|}{ Chí-kvadrát test } \\
\hline & $\begin{array}{l}18-29 \text { let } \\
3 \& 4(\%)\end{array}$ & $\begin{array}{l}30 \text { a více } \\
3 \& 4(\%)\end{array}$ & $x^{2}$ & Sig. \\
\hline $\begin{array}{l}\text { Poskytování služeb (produktů) v rámci } \\
\text { sdílené ekonomiky je spojené s vyšším } \\
\text { rizikem nedodržení dohodnutých podmínek, } \\
\text { než klasický model podnik-zaměstnanec- } \\
\text { zákazník }\end{array}$ & 72 & 81 & 6,460 & 0,011 \\
\hline $\begin{array}{l}\text { Sdílená ekonomika by v České republice } \\
\text { měla být více regulována }\end{array}$ & 63 & 75 & 8,620 & 0,003 \\
\hline $\begin{array}{l}\text { Využívání služeb sdílené ekonomiky je } \\
\text { spojené s vyšším rizikem nekvality služeb } \\
\text { (produktů), než klasický model podnik- } \\
\text { zákazník }\end{array}$ & 62 & 68 & 2,398 & 0,121 \\
\hline $\begin{array}{l}\text { Poskytovatelé platforem se snaží zůstat } \\
\text { anonymní, což je nedůvěryhodné }\end{array}$ & 54 & 64 & 6,264 & 0,012 \\
\hline $\begin{array}{l}\text { Častým motivem pro zapojení subjektů do } \\
\text { sdílené ekonomiky v České republice je } \\
\text { možnost beztrestně porušovat platnou } \\
\text { legislativu }\end{array}$ & 37 & 54 & 16,954 & $<0.0005$ \\
\hline $\begin{array}{l}\text { Využívání služeb sdílené ekonomiky je } \\
\text { bezpečné }\end{array}$ & 45 & 38 & 2,648 & 0,104 \\
\hline $\begin{array}{l}\text { Poskytování služeb (produktů) v rámci } \\
\text { sdílené ekonomiky je bezpečné }\end{array}$ & 50 & 34 & 14,679 & $<0.0005$ \\
\hline $\begin{array}{l}\text { Sdílená ekonomika je v České republice } \\
\text { dostatečně regulována současnými zákony }\end{array}$ & 38 & 27 & 9,155 & 0,002 \\
\hline $\begin{array}{l}\text { Sdílená ekonomika je v České republice } \\
\text { regulována a kontrolována výrazně lépe než } \\
\text { v zahraničí }\end{array}$ & 27 & 17 & 8,714 & 0,003 \\
\hline
\end{tabular}

Zdroj: Vlastní zpracování

Tabulka č. 5 ukazuje, že starší generace (30 let a více) statisticky významně více než generace mladší souhlasí se čtyřmi z devíti zkoumaných výroků, a to s tím, že „poskytování služeb (produktů) v rámci sdílené ekonomiky je spojené s vyšším rizikem nedodržení dohodnutých podmínek, než klasický model podnik-zaměstnanec-zákazník“, „sdílená ekonomika by v České republice měla být více regulována“, „poskytovatelé platforem se snaží 
zůstat anonymní, což je nedůvěryhodné“ a „častým motivem pro zapojení subjektů do sdílené ekonomiky v České republice je možnost beztrestně porušovat platnou legislativu“. Naopak mladší generace (do 30 let) se statisticky významně více než generace starší ztotožňuje s výroky „poskytování služeb (produktů) v rámci sdílené ekonomiky je bezpečné“, „sdílená ekonomika je v České republice dostatečně regulována současnými zákony“ a „sdílená ekonomika je v České republice regulována a kontrolována výrazně lépe než v zahraničí, přesto většina respondentů mladších 30 let s posledními dvěma výroky nesouhlasí. Pouze u dvou z devíti sledovaných výroků statisticky významný rozdíl v názorech podle věku respondentů zjištěný nebyl.

\section{Diskuse a závěry}

Na základě studia dostupných domácích i zahraničních zdrojů Ize dospět k závěru, že ačkoli je sdílená ekonomika vítavým prostředkem přispívajícím ve svém důsledku k udržitelnému rozvoji, není její fungování zatím zcela bez problémů. To je dáno především nejednoznačnou právních regulací na všech úrovních mezinárodního práva i státní správy, kdy mnohdy nejde nové postupy užívané $v$ rámci sdílení aktiv jednoznačně začlenit pod žádný $z$ dosud existujících legislativních rámců. Daná situace je pak mnohdy zneužívána k nekalým činnostem, kdy se některé subjekty snaží vyhýbat různým legislativním i etickým povinnostem a získávají tak neoprávněné výhody. Tím je narušována dobrá pověst celého ekonomického systému sdílení, což je z hlediska nikým nezpochybňovaných výhod sdílení zajisté škoda. To, do jaké míry je právě nedostatečná právní regulace $v$ České republice důvodem nedůvěry, vnímané rizikovosti a odmítání príjetí sdílené ekonomiky z pohledu široké veřejnosti, bylo cílem zjištění námi realizovaného výzkumu.

Ačkoli bylo identifikováno, že nedostatečná právní ochrana, nejasná právní úprava i náročnost naplnění legislativních požadavků hrají dle respondentů při odmítání jejich angažovati v rámci sdílené ekonomiky určitou roli, nelze je označit za důvody dominantní. Mnohem závažnějším důvodem pocitovaným dotázanými občany je nízká informovanost, která jim spolu s nedůvěrou a jistým konzervatismem zabraňují stát se ve sdílené ekonomice uživateli. Neochota či nedisponování vhodnými volnými aktivy i časem jsou pak označovány jako nejčastější důvody respondentů k neposkytování aktiv do sdílení. Zdá se tedy, že primární snahou státních orgánů při snaze o podporu sdílené ekonomiky by mělo být nejenom zajistit správnou míru legislativní regulace, ale i zvýšit úroveň osvěty veřejnosti prostřednictvím informací o ekonomických, společenských i environmentálních výhodách sdílení. Výzkumem tedy nebyla potvrzena hypotéza H1: Hlavním důvodem nezapojeni se českých občanů do sdilené ekonomiky je nejistota pramenící z nedostatečné či nejasné právní úpravy.

Výzkum prokázal, že respondenti v převážné většině (66\% a více) pocitují v rámci sdílené ekonomiky vyšší míru rizika porušení smluvních podmínek a nekvality služeb než 
v klasických obchodních vztazích a většinou (60\%) nepovažuji poskytování ani využívání služeb sdílené ekonomiky za bezpečné. I když většina $(60 \%)$ považuje anonymní poskytovatele platforem za nedůvěryhodné, převážně (52\%) si nemyslí, že by častým motivem pro zapojení se do sdílené ekonomiky byla touha beztrestně porušovat legislativu. Absolutní většina respondentů (69\%) shledává sdílenou ekonomiku v ČR jako nedostatečně legislativně regulovanou, dokonce hůře kontrolovanou než v zahraničí (79\%) a domnívá se, že by regulace měla být zvýšena (71\%). Na základě daných zjištění Ize tvrdit, že výzkum potvrdil hypotézu H2: Občané ČR vnímaji sdílenou ekonomiku jako rizikovou, nebezpečnou a nedostatečně legislativně regulovanou.

Z výše prezentovaných výsledků výzkumu jasně vyplývá, že hypotéza $H 3$ : „Názory na rizikovost, bezpečnost a míru legislativni regulace sdílené ekonomiky v ČR se dle pohlaví, věku a vzdělání respondentů neliší. " byla potvrzena pouze částečně. Rozdíly ve vnímání sledovaných tvrzení podle pohlaví či vzdělání respondentů byly zjištěny pouze v minoritě případů, tudíž odlišnost $v$ názorech respondentů podle těchto proměnných nebyla prokázána a daná část hypotézy se potvrdila. Dle věku se ale statisticky významně lišil postoj respondentů u sedmi z devíti analyzovaných výroků. Na základě získaných výsledků Ize tvrdil, že mladší generace (do 30 let) má statisticky významně příznivější postoj vůči sdílené ekonomice než generace starší (více než 30 let). Příslušná část hypotézy H3 byla tedy výzkumem vyvrácena.

Př́spěvek byl podpořen projektem "Ekonomické, sociální a environmentální aspekty ekonomiky sdílení z pohledu České republiky"; COST Action CA16121.

\section{Literatura}

ANDREOTTI at all. 2017. Participation in the sharing economy: European Perspectives. In: SSRN Electronic Journal. Staženo 2. 9. 2021, dostupný z: https://ssrn.com/abstract=3046550

BALOUNOVÁ, J., JíLKOVÁ, Z. 2018. Správněprávní odpovědnost ubytovatelů Airbnb. In: In: Pichrt, J. a kol. Sdilená ekonomika a delikty. Praha: Wolters Kluwer ČR, ISBN 978-80-7598235-3

BERKOWITZ, H., SOUCHAUD, A. 2019. (Self-)Regulation of Sharing Economy Platforms Through Partial Meta-organizing. In: Journal of Business Ethics, vol. 159, no. 4, p. 961-976, ISSN 0167-4544

BOHÁČ, R. 2019. Daňové aspekty sdílené ekonomiky - dva roky poté. In: Pichrt a kol. Sdilená ekonomika tři roky poté - závěry a perspektivy. Praha: Wolters Kluwer ČR, ISBN 978-80-7598591-0

COHEN, M., SUNDARARAJAN, A. 2015. Self-regulation and innovation in the peer-to-peer sharing economy. In: University of Chicago Law Review Dialogue, vol. 82, no. 1, p. 116-133.

CONNOLLY, J.M. 2021. No Uber, no tourists? Public attitudes toward municipal regulation of the sharing economy. In: Local Government Studies, vol. 47, no. 2, p. 331-346, ISSN $0300-$ 3930 
DEMOVÁ, K. 2018. Crowdwork a pracovní trh Evropské unie. In: Pichrt, J. a kol. Sdílená ekonomika a delikty. Praha: Wolters Kluwer ČR, ISBN 978-80-7598-235-3

DUNNE, N. 2018. Competition Law (and Its Limits) in the Sharing Economy. In: Cambridge Handbook on Law and Regulation of the Sharing Economy. Staženo 8. 9. 2021, dostupný z: https://papers.ssrn.com/sol3/papers.cfm?abstract_id=3058697

ECKHARDT, G.M., BARDHI, F. 2015. The sharing economy isn't about sharing at all. In: Harvard business review, vol. 28, no. 1, p. 881-898.

ELISCHER, D., MOCEK, O. 2018. Sdílená ekonomika aneb kde leží břímě odpovědnosti? In: Pichrt, J. a kol. Sdilená ekonomika a delikty. Praha: Wolters Kluwer ČR, ISBN 978-80-7598$235-3$

ERTZ, M., DURIF, F., ARCAND, M. 2019. A Conceptual Perspective on Collaborative Consumption. In: AMS Review, vol. 9, no. 1-2, p. 27-41, ISSN 1869-814X

Evropská komise, 2016. Sdělení Komise Evropskému parlamentu, Radě, Evropskému hospodářskému a sociálnímu výboru a Výboru regionů. Staženo 8. 9. 2021, dostupný z: Evropská komise - oficiální internetové stránky (europa.eu)

Evropský parlament, 2019. Transparentní a předvídatelné pracovní podmínky v Evropské unii. Staženo 20. 9. 2021, dostupný z: www.europa.eu

FAJAR, M. 2020. Fair Competition: The Concept of Regulation in the Sharing Economy. In: Journal of Asian Finance, Economics and Business, vol. 7, no. 11, p. 637-645, ISSN 22884637

Finanční správa, 2017. Informace k daňovému posouzení povinností poskytovatelů ubytovacích služeb (Airbnb a další). Staženo 20. 9. 2021, dostupný z: www.financnisprava.cz

Finanční správa, 2018. Neplatičům daní z řad uživatelů Uberu i Airbnb každý den nabíhají pokuty z prodlení. Staženo 3. 9. 2021, dostupný z: www.financnisprava.cz

FRENKEN, K., SCHOR, J. 2017. Putting the sharing economy into perspective. In: Environmental Innovation and Societal Transitions, vol. 23, p. 3-10, ISSN 2210-4224

FUSTER, M.M., ESPELT, R., SENABRE H.E. 2021. Data for Sustainable Platform Economy: Connections between Platform Models and Sustainable Development Goals. In: Data, vol. 6, no. 2 , p. 7 , ISSN $2306-5729$

GREGUŠ, J., ADAMIČKA, M. 2019. Platformová práca v prostředí zdial'anej ekonomiky. In: Pichrt a kol. Sdilená ekonomika tři roky poté - závěry a perspektivy. Praha: Wolters Kluwer ČR, ISBN 978-80-7598-591-0

HÁJEK, J. 2019. Sdílená ekonomika - je možné ji zdanit? In: Pichrt a kol. Sdílená ekonomika tři roky poté - závěry a perspektivy. Praha: Wolters Kluwer ČR, ISBN 978-80-7598-591-0

HEINRICHS, H. 2013. Sharing economy: A potential new pathway to sustainability. In: GAIA, vol. 22, no. 4, p. 228-231, ISSN 0940-5550

HONG, S., LEE, S. 2018. Adaptive governance and decentralization: Evidence from regulation of the sharing economy in multi-level governance. In: Government Information Quarterly, vol. 35, no. 2, p. 299-305, ISSN 0740-624X 
CHAFFEE, E. C., RAPP, G. C. 2012. Regulating online peer-to-peer lending in the aftermath of Dodd-Frank: In search of an evolving regulatory regime for an evolving industry. In: Washington \& Lee Law Review, vol. 69, no. 2, p. 485-533, ISSN 0043 - 0463

IPSOS, 2020. Zájem o sdílenou ekonomiku roste, vyzkoušel ji už každý třetí Čech. Staženo 29. 9. 2021, dostupný z: www.ipsos.cz

JELÍNKOVÁ, M.; TETŘEVOVÁ, L.; VÁVRA, J.; MUNZAROVÁ, S. 2021. The Sharing Economy in the Context of Sustainable Development and Social Responsibility: The Example of the Czech Republic. In: Sustainability, 2021, vol. 13, no. 17, p. 9886, ISSN 2071-1050

JONES, M. 2014. Territory, politics, and relational autonomy. In: Territory, Politics, Governance, vol. 2, no. 2, p. 109-114, ISSN 2162-2671

KLÍMA, P. 2019. Alternativní přepravní (taxi) služby v českém a evropském kontextu. In: Pichrt a kol. Sdilená ekonomika tři roky poté - závěry a perspektivy. Praha: Wolters Kluwer ČR, ISBN 978-80-7598-591-0

KONUPKOVÁ, J. 2018. Legitimita dovozování deliktní odpovědnosti za jednání účastníků sdílené ekonomiky. In: Pichrt, J. a kol. Sdílená ekonomika a delikty. Praha: Wolters Kluwer ČR, ISBN 978-80-7598-235-3

KUBEŠOVÁ, J. 2019. Ochrana „digitálních nádeníkư“. In: Pichrt, J. a kol. Sdílená ekonomika a delikty. Praha: Wolters Kluwer ČR, ISBN 978-80-7598-235-3

LEE, J. W., TAN, W. N. 2019. Global Corporate Citizenship: Cross-cultural Comparison of Best Practices in the Global Automotive Industry. In: Journal of Asian Finance, Economics and Business, vol. 6 , no. 1, p. 261-271, ISSN 2288-4637

Ministerstvo financí České republiky, 2021. MP/03/2021 - Poplatek z pobytu. Staženo 21. 9. 2021, dostupný z: www.mfcr.cz

PARK, M. 2020. The sharing economy, regulations, and the role of local government. In: International Journal of Tourism Cities, vol. 6, no. 1, p. 158-174, ISSN 2056-5607

PAWLICZ, A. 2019. Pros and cons of sharing economy regulatio. Implications for sustainable city logistics. In: Proceedings Paper of 3rd International Conference on Green Cities - Green Logistics for Greener Cities, vol. 39, p. 398-404, ISSN 2352-1465

PICHRT, J. 2018. Memoranda, ubytovací poplatky ... a co dál? In: Pichrt, J. a kol. Sdilená ekonomika a delikty. Praha: Wolters Kluwer ČR, ISBN 978-80-7598-235-3

PICHRT, J. 2019. Ekonomika sdílení tři roky poté. (str. 13-18) In: In: Pichrt, J. a kol. Sdilená ekonomika a delikty. Praha: Wolters Kluwer ČR, ISBN 978-80-7598-235-3

SOBĚHART, R. 2018. Sharing economy regulation in the Czech Republic: The theoretical framework of analysis. In: Littera Scripta, vol. 2, p. 106-115, ISSN 1805-9112

STAŠA, J. 2018. Sdílení vs. Podnikání. In: Pichrt, J. a kol. Sdílená ekonomika a delikty. Praha: Wolters Kluwer ČR, ISBN 978-80-7598-235-3

TKADLEC, M. 2018. Regulovat, či neregulovat Airbnb? To je oč tu běží! In: Pichrt, J. a kol. Sdilená ekonomika a delikty. Praha: Wolters Kluwer ČR, ISBN 978-80-7598-235-3 
TOMASELLI, V. at all. 2021. Methods, Developments, and Technological Innovations for Population Surveys. Social Science Computer Review, nu. 089443932199421, ISSN 08944393

VICENTE, M.R., GIL-DE-GÓMEZ, C. 2021. Exploring the Motivations of Suppliers in the Collaborative Economy: A Sustainability Approach. In: Sustainability, vol. 13, no. 5, p. 2465, ISSN 2071-1050

VYBÍRAL, R. 2018. Delik(á)tní aspekty sdílené ekonomiky v daňovém právu. In: Pichrt, J. a kol. Sdílená ekonomika a delikty. Praha: Wolters Kluwer ČR, ISBN 978-80-7598-235-3

WEGMANN, J., JIAO, J. 2017. Taming Airbnb: Toward guiding principles for local regulation of urban vacation rentals based on empirical results from five US cities. In: Land Use Policy, vol. 69 , p. 494-501, ISSN 0264-8377

WHELAN, G. 2017. Political CSR: The corporation as a political actor. Staženo 8. 8. 2021, dostupný z: https://ssrn.com/abstract=2726174

YU, T., SHEN, W. 2019. Funds sharing regulation in the context of the sharing economy: Understanding the logic of China's P2P lending regulation. In: Computer law \& security review, vol. 35, no. 1, p. 42-58, ISSN 0267-3649

\section{Adresa autora}

Ing. Martina Jelínková, Ph.D.

Univerzita Pardubice

Fakulta chemicko-technologická

Katedra ekonomiky a management

Studentská 573, 53210 Pardubice II

Česká republika

E-mail: martina.jelinkova@upce.cz 